\title{
Hercule Poirot and the Tricky Performers of Stereotypes in Agatha Christie's Murder on the Orient Express
}

\section{ABSTRACT}

Agatha Christie's Murder on the Orient Express (1934) remains well-read, and its hero Hercule Poirot continues to enjoy popular currency. Yet the text has not aged well due to some of its now clichéd plot developments and dialogue, as well as Christie's depiction of class, ethnic and national prejudices in it and her other novels. This study hopes to re-energize discussion on Murder by finding defensible reasons for its apparent flaws. Not only do the stereotypical behaviors of the passengers narratively distract Poirot and the reader from a solution, but their flaws serve as foils against which Poirot's heroic gravitas and cultural values are positively contrasted. Further, criticism often misses the point that the passengers are performing their behaviors, and if so, the deployment of stereotypes as only acted performances destabilizes them as permanent aspects of national or ethnic identity. Can Murder then be read as an anti-racist text?

Keywords: Agatha Christie, Murder on the Orient Express, Hercule Poirot, detective fiction, British fiction, prejudice, stereotypes. 


\section{INTRODUCTION}

Dame Agatha Christie's Murder on the Orient Express (1934) has been a perennial success, in terms of print sales and cinema and stage adaptations, and in 1974 alone the book reputedly sold three million copies following the release of that year's film version, directed by Sidney Lumet. The novel and its detective hero Hercule Poirot are now familiar tropes in popular culture. Yet reading Murder has now become a dubious pleasure. Its classic whodunit plot unfortunately coexists with what appear to be unpleasant and offensive ethnic stereotypes from the time period, and these features have been criticized in recent scholarship. Taking the novel's film adaptations as models, directorial responses to the "problem" of these stereotypes have included downplaying them while ironizing the story and lowering Poirot's stature. In brief, the argument in this study is that the censure of these claimed stereotypes, whether on stylistic or ethical grounds, misses the point that the passengers "act" their behaviors. These performances comprise a necessary plot element in both distracting the reader and Poirot from the solution and situating him as a heroic figure. Moreover, rather than perpetuating ethnic stereotypes, Murder problematizes them by situating them as merely superficial chosen performances. What I hope to show is that while Murder may remain guilty of class elitism, it bears some signs of being an anti-racist text. As a coda, I also refer to the film and television versions of Murder from 1974 to 2017 to highlight how the story suffers narratively by comparison when the stereotypes are "fixed."

\section{MURDER AND CRITICISM}

Murder on the Orient Express has been described with the same dry joke that is applied to Shakespearean plays, that it would be better if it did not have so many clichés. Much of the novel's enduring attraction involves Christie's recurrent "flâneur-detective" (Dalal 269) Hercule Poirot, and despite her later exasperation with a protagonist she called "bombastic, tiresome, [and] egocentric" (qtd. in Gore-Langton), the diminutive mustachioed Belgian remains a recognizable figure: in 1975 Poirot was the first fictional character to have an obituary printed in the New York Times. Murder's authorizing tropes are familiar when referenced in popular media: the Belle Époque glamour of its train setting, its sometimes overtheatrical dialogue, and the surprise ending which reveals that everyone did it. In popular culture Murder has been the subject of innumerable parodies and pastiches. A YouTube search yields television spoofs ranging decades, with Poirot (over)played by Benny Hill, John Candy and Jason Alexander, 
and social media mashups combining Star Wars or Downfall, with Bruno Ganz's Hitler explosively nitpicking over the 2017 Kenneth Branagh film version. Murder further iterates into graphic novels, comic books (with Poirot portrayed by Homer Simpson), social media memes and video games. ${ }^{1}$ Poirot and the Murder story kernel arguably constitute a strand of cultural capital even for those who have not read it, and its influence extends as far as the Hardy Boys, Cadfael and Dr. Who.

In scholarship, Murder and "the queen of crime" have fared less well. Criticism may be roughly divided into interwar and postwar debates on Agatha Christie's place in the canon and the detective novel genre's literary status, and into more recent controversies regarding its putative racism and ethnic stereotypes. Virginia Woolf derided middlebrow fiction as a "mixture of geniality and sentiment stuck together with a sticky slime of calf's-foot jelly" (qtd. in Schaub 12), tying Murder to earlier Victoriana replete with fusty butlers and Colonel Mustards who "did it in the library with a candlestick" (Suits 201). Postwar commentary continued to diminish Christie's work as disposable commercial fiction, with critics disparaging her as "a depressingly successful perfecter of the art of the readerly cluepuzzle" (Hark, "Impossible Murders" 111) for her "automated production line" (Lassner 31) of stock plots and clichés mechanically advancing towards a predictable resolution. Even contemporary literary peers such as Raymond Chandler cattily summed up Murder as Poirot trudging through "a series of simple operations, like assembling an egg-beater," with the result that "only a half-wit could guess" (Chandler).

In the twenty-first century, such high-low culture partitions have been questioned in postmodern dialogue, or are dismissed as quaintly snobbish. But Christie's sensibilities have not aged well. Academia now attaches a subversive noir chicness to the American "hard-boiled" detective novel, but the more conservative English subtype has not benefited from this rehabilitation, and newer scholarship is careful to concede that Christie feels "trivial, dated, classbound" (Barnard 7). Murder's contemporaneity with the sensational kidnapping of Charles Lindbergh's baby in 1932 now has little topical currency, and the "rich, sophisticated, salon-like atmosphere" (Dalal 268) of train travel has dwindled in a culture where even the cachet of airplane travel is only evoked nostalgically in television shows such as Mad Men. Christie's world appears an antique one threatened by the encroaching spectres of Bolshevism and "modern morals," and

1 YouTube clips: Benny Hill (https://youtu.be/zBvLanL8XpM); John Candy and SCTV (https://youtu.be/CTpSO5v1qKY); Muppets Tonight with Jason Alexander (https:// www.youtube.com/watch?v=ttYc3ZWpWQc); Star Wars VIII (https://www.youtube. com/watch?v=PT-CIvvvt6s\&t=7s); Downfall (https://youtu.be/EhDzbO_6OlE)—all retrieved 7 October 2019. 
much of her work displays a "discomfort with modernity" (Hawkes 195). Christie never "gets" the 1950s Angry Young Men or 1960s hippies who squander their proud British Empire legacy via enervating leftism and the welfare state (Prior 207), and her later novels such as Third Girl (1966), with its stilted mocking of youth culture and a Poirot still inhabiting a WWI-era milieu, can read as painfully dated. Christie was a lifelong Tory, and Matthew Beaumont posits that Murder replays a Victorian-Edwardian conservatism in that "the narrative nostalgically reinstates an order that no longer exists" in its close when this bourgeois group "can safely proceed to Europe across the ominous spaces of the East" (Beaumont 18).

Worse, where Christie's cardboard character-painting was once merely criticized as a stylistic limitation, in the present climate it has left her open to accusations of bigotry or racism. George Grella surveys the interwar whodunit novels and notes that ethnic foreigners, along with cads and adulteresses, are expedient victims as they provide rationalized motives to their murderers - thus a satisfying ending is engineered when both the killer and the doubtful outsider are cleansed from the social circle of "our type” (41). Christie's novels particularly suggest both period racism and xenophobic Anglocentrism, with her world a fossilized Little England menaced by the Other. She held a defensive, embattled view of the British Empire that was problematic even by the 1960s: "foreigners of all kinds are either comic or suspicious" (Barnard 15), her indigenous characters can do no more than epitomize chaos and the need for paternal colonial rule (Allmendinger 61), and her "clear racial demarcation of non-whites as troubling, temporary interlopers in an otherwise white Britain” (Prior 201) resonated squeamishly in the Enoch Powell years. She held a particular disdain for Jews, calling an early character "Noseystein" (Lassner 31), but disparaged everyone from Canadians to Catholics to Syrians (Pendergast 392-94). Nervous editors later resorted to bowdlerizing her books, for example re-titling Ten Little $N^{* * *}$ ers (1939) to And Then There Were None (Allmendinger 60).

Yet it may be said that Christie portrays some caricatures humorously, and that she did not spare the English from her barbs; she writes of a tourist that "unlike most English people, she was capable of speaking to strangers on sight instead of allowing four days to a week to elapse before making the first cautious advance" (qtd. in Ro). She also evolved. Her anti-Semitism lessened when events in the 1930s made jokes about Jews insensitive and unfunny, and in her memoir she relates an incident around 1933 when she was shocked at meeting a real Nazi who advocated their extermination (An Autobiography 465). For all her "blimpish social attitudes" (Slung 67), morality is not inexorably tied to social status in her texts (Hawkes 203). Despite Christie's conservatism she portrayed 
some strong and actualized females (Slung 65), and for her time was sympathetic toward homosexuality (Lutkus 74). Alison Light also argues that her reputation as a hyper-English "high priestess of nostalgia" via lavish periodized television adaptations reflects 1980s Toryism more than Christie (Light 62-63). In Light's reading, Christie's Edwardian tableaus are undercut by subtle modernist touches of parodic wit, with older tropes and phrases ironized or mixed anachronistically- "one cannot imagine Watson getting 'fed up' as Hastings does” (68).

Murder on the Orient Express seems to complicate rather than resolve these accusations, for while there are references to Arabs and "useless foreigners" (39), the story is not really "oriental" in subject at all-the initial setting of Istanbul conjures exotic intrigue but plays a nugatory role (Dalal 270). Middle Easterners are mentioned, but not one is a significant character. The train passes through suitably glamorous and exotic environs, yet the story has little interaction with them, as its events take place in a locked coach (Linares 16$)$. The crime and resolution are only notionally about place-they happen nowhere, in a static interior space, in the blank snow of the countryside (King 9,11). Nor are the passengers evenly genteel. No one is poor in the train's first-class section, but the travelers peak with Dragomiroff's aristocratic status and end far down the socioeconomic line with servants and car salesmen. Despite the claim that "these are books about luxury" (York 135), the train projects the authorizing marks of high status rather than its passengers, who consume such prosaic fare as eggs and coffee. Only Poirot and Bouc, his friend and a Wagons-Lit official, are seen drinking wine, and Mrs. Hubbard's cognac is medicinal.

Nevertheless, Murder elsewhere rather condemns itself. The text is obsessed with the characters' nationalities and their consequent stereotypical proclivities (King 12). During the first morning Bouc's panegyric on the diversity of the passengers is too loaded not to see that it will figure into the crime:

"All around us are people, of all classes, of all nationalities, of all ages. For three days these people, these strangers to one another, are brought together. They sleep and eat under one roof, they cannot get away from each other. At the end of three days they part, they go their several ways, never perhaps to see each other again."

"And yet," said Poirot, "suppose an accident-"

"Ah, no, my friend-"

"From your point of view it would be regrettable, I agree. But nevertheless let us just for one moment suppose it. Then, perhaps, all these here are linked together-by death."

"Some more wine," said M. Bouc, hastily pouring it out. "You are morbid, mon cher. It is, perhaps the digestion." (24) 
One expects a peal of thunder, or theater organ trill. The story never allows us to forget its characters' nationalities. Like Chaucer's pilgrims who are named by their work, Murder's passengers are "the American lady" and "the Italian." In Poirot's list of clues nationality always follows names and figures prominently in his deductions. While he does chide Bouc, "How you harp on your Italian!" (114), in debating the killer's identity with his colleagues Poirot argues that the crime is an Anglo-Saxon one of design and not a Latin one of passion (146), not that the distinction is frivolous or misleading.

The academic modus vivendi in approaching the awkward fact of Christie's popularity and cultural resonance with her occasional stereotypes has usually involved some patronizing admission that Christie is a product of her time, and that the past is a foreign country. It feels unsatisfying for Christie and Murder to be forever blushed past with a critical asterisk, and so I would like to attempt an exoneration. First, at a formal level, the ethnic stereotypes have performative functions in Christie's narrative: they usefully distract the reader and Poirot; further, they underscore the reader's sympathy for and identification with him, for the stereotypes reliably make Poirot look more heroic and justified by comparison. Second, we need to be reminded (often) that the passengers are pretending to be clichéd tourists from their respective nations, for their stereotypical behaviors are finally revealed as a ruse to misdirect Poirot. If negative stereotypes are thus merely volitional acts and not inherent attributes, Murder should be less subject to criticism for them-and may arguably be read as an anti-racist text.

\section{POIROT AS NORMATIVE MORAL REFERENCE POINT}

Part of the fun of a whodunit is being offered false solutions and dead ends, and so a first line of defense for Murder is that its stereotypes serve this purpose rather than being gratuitous. The nationalities of the passengers create distracting assumptions among Poirot, Bouc and Constantine and likewise tempt the reader without the author breaking the rules by "overtly stat[ing] false information" (Bargainnier 39). The English passengers" reserve suggests they are unlikely to undertake a violent murder, and the Americans' penchant for over-sharing suggests they cannot keep one secret. Merja Makinen agrees that Christie deploys "erroneous prejudices" that divert the reader (416), and Ina Rae Hark adds that for Christie to stress the diversity of the passengers makes it less probable and ergo more dramatic that such a polyglot group would collude ("Twelve Angry People" 40). The too-pat distribution of "such an assembly" (Christie, 
Murder 253) ironically prompts Poirot's suspicions when he muses "only in America ... there might be a household composed of just such varied nationalities—an Italian chauffeur, an English governess, a Swedish nurse, a French lady's-maid" (253).

Another usual component of the detective genre is the predominant role of the protagonist in the narrative. He or she serves as the story world's index point, and so the books are subtitled as Poirot mysteries; they are about him and his mental machinations in solving the case. Normally the detective occupies an unequal position of power by having more information with which to surprise the reader and other characters (Singer 158). The reader may fancy him or herself a sleuth, but is unlikely to know "the killing distance of a South American blowgun, the rate at which curare is absorbed into the bloodstream, or the effects of an English summer on the process of rigor mortis" (Grella 31). One can save face in feeling superior to the befuddled Watson or Bouc, which is partly why they are there, while aspiring to be as logical as Sherlock Holmes or as sophisticated as Dorothy L. Sayers's Lord Peter Wimsey.

Christie reliably conforms to this norm in Murder. Its narrator has unusually little presence (Bright 47), and so the story largely uncritically relates Poirot's values and perceptions, and there is little ironic detachment from him. The novel never substantively questions Poirot or challenges his worldview. Christie once mused that she was of a more innocent generation who thought "the enemy was wicked, the hero was good" (An Autobiography 437), and Poirot occupies such an uncomplicated role "almost defiantly" against period trends (Martin). Nor did Christie have much regard for psychology as a discipline (qtd. in Hawkes 205) or evidently for the view of truth as contingent and unstable. Even if Poirot's methods are more emotional than Sherlock Holmes's, truth and goodness ultimately do exist and are attainable even when order and civilization are "floundering in the mud of the Somme" (Hawkes 200). For Christie "the forces governing the world are both benign and logical" (Martin), and it is assumed to be possible for Poirot to impose the same sort of stable truth integrity on the situation as the novel's view of reality assumes.

Thus whether Christie is serious or partly sardonic in denigrating Poirot, nothing signifies that he is ironized or less than the epicenter of the story's weltanschauung. Christie's daughter once forbade actor David Suchet from playing Poirot as a comic character on television, warning that "people can smile with him, but never laugh at him" (qtd. in "Poirot is not Comical"). If Mary Debenham considers Poirot "a ridiculous-looking little man" (Christie, Murder 6) or MacQueen thinks his name sounds like "a woman's dressmaker" (50), these disparaging views are never permitted to be vindicated by events. It is always others who are wrong for misjudging Poirot by his surface quirks, 
and the reader is invited to conspiratorially grin at their mistake and anticipate their comeuppance when they learn who this man is. The hero who earns the audience's approval by discomfiting those who underestimate him is a trope going back to Odysseus returning home dressed as a beggar, and it is no less satisfying when arranged here. The reader, surprised by unexpected turns, sees that the passengers also have the same experience.

Thus although Poirot may initially be perceived by the passengers as foreign and marginalized, the reader has already been shown that his position is the finer and valorized one. Within the pre-jet set strata where Poirot moves he is "an important passenger" (3) who receives telegrams from important people and goes to important places. Unlike the train's tourists, he "belong[s] to the world" (124), endowing him with a cultivated sophistication beyond their parochialism. His continental values are assumed to be the natural and proper ones of an international gentleman. Poirot and his friends are always at each other's "service" $(47,118)$, and courtesy and honor are unquestioned genteel virtues; we hear of honor twice, once when it is that of the French army, chivalrously maintained by Poirot, and at the end when he refers to it in retiring from the case $(4,265)$. Chris Ewers notes that the historical Wagons-Lits line was a triumph of continental standardization, but it is odd that he writes that "Poirot is strangely at home in such a milieu" (109) —it is anything but strange, for being among the movers and shakers is precisely Poirot's home, and both he and the train mutually inscribe cosmopolitan prestige.

Language is another index of Poirot's elevated status. Far from his non-Anglophone origins isolating or stigmatizing him (Munt 8), the lingua franca of café society is his French as a Belgian. It is taken as a matter of course that the concierge at the Tokatlian in Istanbul speaks French (Christie, Murder 15) and that it is the working language of the train line. That well-bred passengers should address staff en français (“Ce n'est rien. Je me suis trompé”-“It's nothing. I was mistaken” 35) is natural, and it does not appear to pique Poirot's suspicions that the xenophobic Mrs. Hubbard knows what "encore un peu” (169) means. In dialogues between Poirot, Bouc and Dr. Constantine, gestures of politeness in French are unfailing ("Après vous, Monsieur," "Mais non, après vous"- "After you, sir," "Why no, after you" 72), along with recurring terms of endearment (mon vieux, mon cher-my old friend, my dear one). In interactions with other passengers Poirot inhabits the same mores of continental etiquette, bowing to Ratchett (28) and calling him monsieur. Exchanges are conducted with graceful discretion: tact is mentioned twice by Poirot $(106,122)$, and indecorous speech is avoided except where it is patronizingly excused as an "American expression," such as "bumped off" (45) and "once-over" (126). 
Scholarship seems to have obstinately missed this insistent glamorization of Poirot's status and potency, calling him an "affront to English masculinity" (Rowland 63) or a "parody of the male myth" (Munt 8), or linking him to "kindly elves" Puck and Ariel (Grella 38), parsing him as surmounting his foreignness only because he "represents no sexual threat" (42). Hall and Plain argue that muscular heroism became taboo in postwar England, and if so, perhaps Poirot's vitality is retroactively minimized by such a taboo. At best there is the defense that his effeminate fastidiousness again lures others to underestimate his competence (Heilbrun 4). Yet such readings are unpersuasive, for seeing Poirot as a sexless outsider making safe comments on the English also implies an ironic reading of the equally un-British Orient Express that he is so closely associated with. If it is true that Poirot is so anodyne, then why is everyone in the story inevitably awed by him? For those in the know, Poirot is deferred to; he is groveled to by the French army, he daunts Lieutenant Dubosc, and he displays a proprietary authority over the train, behaving coequal to Bouc, if not taking command once given the case. He reduces both Bouc and Constantine to nervous foils who sputter "It is madness!" (Christie, Murder 166) while he steely deliberates. At the case's end, although he officially defers to Bouc to choose between two solutions, it is Poirot who has set the choices. The events provide an agreeable counterfactual scenario of "how the Lindbergh case might have turned out" (York 138) had heroic Poirot been in command.

\section{THE PERFORMANCE OF MURDER'S STEREOTYPES}

These two threads connect to a third, for just as the apparent irksome stereotypes of the passengers distract the reader from the solution, their behavior also endorses Poirot by contrast, thus reinforcing his central position as sympathetic hero. Where Poirot's deportment has the proper conviviality and dignity, the English lack the former and the Americans the latter. It does not undercut this valorization of Poirot to learn that the passengers were performing these clichés in order to misdirect him.

A first example is the British, who are indeed "not chatty" (Christie, Murder 9). While all the passengers have an interest in not betraying themselves, the cold aloofness that the English present is juxtaposed against the warm bonhomie of Poirot among his peers Bouc and Constantine. In his interview Masterman is superficially polite, with a "sir" after nearly every utterance, but his face is "inexpressive" and only once "held positive warmth and feeling" $(91,92)$. The novel does not criticize formality itself, for Poirot is also correct in conduct, but rather its motive, which for 
Poirot and Bouc is gracious manners and for Arbuthnot and Debenham is contempt. One of Christie's stock types is the haughty, harrumphing English officer, and Arbuthnot's minimal replies convey to Poirot that he is considered an "interfering little jackanapes" (126), and the narrator posits that Arbuthnot is "uninterested in what a pack of foreigners called anything" (125). The apex of unhelpful sangfroid appears in Mary Debenham, whose "calm and unruffled" voice (147) issues noncommittal non-answers such as "I hardly noticed him" and "I cannot say I thought about it" (148). When Poirot becomes sardonic in order to goad a response, Debenham articulates resentment but maintains her evasiveness: "I don't know" and "It's difficult to say" (151).

The apparent behaviors of the Americans and Italian-American also serve to elicit respect for and identification with Poirot by contrast. The American directness about hard cash is gauche among the refined circles of a detective amateur, for Poirot delicately avoids it-he accepts the case out of friendship and diversion and not remuneration (47), and he asks Foscarelli to "pray confine yourself to the point" (144) when the former tries to regale him with sales figures. Christie is fond of following scenes of Poirot's verbal elegance with American brusqueness, and immediately after a charmingly amiable encounter with Bouc in the Tokatlian they hear Ratchett's rat-a-tat "Pay the bill, Hector" (17) and grunt. In the dining car, Poirot and Bouc's eloquent rumination on Balzac is again followed by Hardman monosyllabically telling Foscarelli 'You've got to put it over big" (25) and Mrs. Hubbard kvetching about meal bills and tipping. After this follows Poirot's tête-à-tête with Ratchett, where Poirot's pecuniary discretion is set against Ratchett's crassness in urging that Poirot prostitute his services for "big money" (30). If Poirot is small, big is consequently bad, for it is invariably attached to examples of American tackiness in yet more monosyllabic adjectives, such as declaring Hardman is "a big American in a loud suit" (24).

Added to the American brusqueness is their lack of adult self-restraint. The Americans, excepting Ratchett, are not unfriendly; rather, they have no filter. Poirot might prefer more reserve in Mrs. Hubbard, who carps with insular witlessness about foreign currencies being "a lot of rubbish" (28). By the first day he "knew all about Mrs. Hubbard's daughter. Everyone on the train who could understand English did!" in addition to "what she thought of the Turks and their slipshod ways" (33), and the narrator's evident agreement is expressed in the sarcastic use of the exclamation point. Conspicuously far from the erudite repartee between Poirot, Bouc and Constantine, Mrs. Hubbard's prattling is notably juvenile, and Poirot interacts with her as if she were a babbling child, treating her "soothingly" (100) when she gives her deposition. Foscarelli is treated with similar 
paternalism; he has a "childish face" (143) and Poirot interrupts him like an annoyed parent three times in his deposition to recall him to the topic (144). In contrast to Poirot's verbal propriety, the Americans use colloquialisms and profanities-Mrs. Hubbard is fond of "kinder," kind of $(97,104)$, and even the likeable MacQueen blurts out that Ratchett is a "damned skunk" (83).

Even if Murder can be shown to have reasons for its stereotypes, they are arguably still present and reflect Christie's choices. Yet the fact that the passengers perform their stereotypes is additionally interesting insofar as how they behave after being unmasked. As their act unravels, both Arbuthnot and Debenham lose their coldness; when Poirot exposes Debenham as the Armstrong governess, Arbuthnot switches from being "carved out of wood" (236) to protesting, "I'll break every bone in your damned body" (239) while defending Debenham, addressing her by her first name. She similarly shifts from defiant equivocation- "it is true that I lied to you" (238) — to breaking into tears. Foscarelli's machismo equally disappears as the narrator notes, "All the assurance and geniality had gone out of his manner" (243). Although the German and Swedish domestics do not speak later, their revealed ability to sustain the conspiracy belies their presumed simple wit. Further, when the overblown stereotypes are no longer useful the passengers take on a sympathetic amiability unlike their prior stereotypical quirks: Masterman gently avers to Poirot that Foscarelli "wouldn't hurt a fly" (246), and as the passengers enter the restaurant car, Mrs. Hubbard comforts the Swedish lady with a quiet kindness different from her earlier strident narcissism. After the resolution, Mrs. Hubbard and Arbuthnot display further maturity and generosity; Hubbard confesses their actions with a grace lacking in her prior vanity, volunteering to "lay the blame upon me and me only" (264), and Arbuthnot tenderly adds that Armstrong "saved my life in the War" (263), without his earlier diffidence.

If it is true that Christie economizes by giving her characters easily recognizable single personality traits in order to focus on exposition (Bargainnier 39), for them to lose those sole traits is a considerable change. However, again, there is perhaps a subtle message accompanying this alteration, for such stereotypes evidently have little purchase if they can be chosen and discarded at will. If ethnic and national behaviors are not inherent to those who display them but are merely chosen and temporary performances, Christie ultimately problematizes such stereotypes. Foscarelli's Italian-ness and Arbuthnot's English-ness are, evidently, nothing, and whatever identity traits seemingly divided the passengers are shown to be chimerical.

The novel's last scene is illustrative of these several points, for Poirot's solution to fabricate a culprit in order to spare the passengers from arrest 
and shame, while protecting the Wagons-Lits name, certifies his preference for practical community restorative justice and "honor" over abstract law. Everyone admittedly enjoys a personal benefit from going along with Poirot's ruse, but by privileging these moral aims over punishing a death that no one regrets anyway (Christie, Murder 71) Poirot normalizes his own values over everyone on the train, and the previously arrogant and garrulous passengers are now silent. Constantine takes back his objections, and two passengers, Arbuthnot and Debenham, are even romantically united by Poirot's principled forgery. It is not hard to see the 1934 Murder as a comedy in the medieval sense of a story with a happy ending, for its Poirot/Prospero figure contrives to bring about a harmonious outcome with a possible future marriage.

\section{CASE STUDY: MURDER ON THE SCREEN}

While this paper's emphasis is not film studies, comparison between the Murder text and film versions may be additionally revealing. If Murder's stereotypes endorse Poirot by contrast, and if their exposure as temporal acts tends toward discrediting them, it might help to speculate how the Murder narrative would differ if Poirot were not valorized and the stereotypes did not function in this way. But this is exactly what happens in the film and television adaptations of the novel. The first Murder film, Sidney Lumet's in 1974, is something of a gold standard in terms of authorial sanction, as it was one of only two film adaptations of her books that Christie liked (Mills 44), and its premiere was her last public appearance. As any influence Christie has over her films ceases and we move towards the present, it is a useful litmus test to see how her assumptions about Murder are reinterpreted in order to conform to newer sensibilities.

True to expectation, over time in film the novel's views are given ironic or comic distancing, and the visuals are archaized with a heavily stylized art deco look. Poirot's gravitas equivalently shrinks. The 1974 Poirot incorporates only minor idiosyncrasies, having him don gloves to read a newspaper. But in later versions, his now- "ridiculous mustache" (Marine) grows, so that by the 2017 Kenneth Branagh movie it is a comically distracting spectacle noted by other passengers and in commentary for the film. The 2017 production further endeavors to democratize Poirot against others by adding bizarre obsessive-compulsive quirks, so that he sends back eggs that are not identically sized, continually asks staff to straighten their ties, and rudely calls Bouc's companion a prostitute. As a detective the 2017 Poirot is closer to the American "private dick" type, conforming to the trope of being disaffected from society or damaged by personal 
emotions in the case, such as revenge or lost love (Cawelti 332-34); he protests that he "needs rest" and must be browbeaten by Bouc into taking the case, and his objectivity is compromised by guilt as a result of receiving a letter from Armstrong requesting help at the time of the kidnapping.

Comparison with the more emotionally charged film presentations of the final exposure scene is again absorbing in view of how later directors diminish Poirot's stature. In the 1934 text Poirot remains in control and only two passengers speak, and his decision is made with such finality that the book has nothing more to do but end. As each film presents a new iteration of the story the travelers are less deferential. In the 1974 Lumet version they are told to not interrupt Poirot and quietly say "Hear, hear" only at his close; in the 2010 Philip Martin production Arbuthnot threatens to shoot Poirot and is restrained by Debenham (Makinen and Phillips 48); and in the 2017 Branagh film Arbuthnot does shoot at Poirot and the passengers interrupt and challenge him. Congruently, Poirot's moral certainty attenuates. At the close of the 1974 film the relieved passengers clink glasses and Albert Finney's Poirot comments wryly to Bouc, "Now I must go and wrestle with my report to the police-and with my conscience." But by the 2010 version Poirot anxiously accuses the passengers of rigging a "kangaroo jury," stating that "the rule of law, it must be held high" and rejecting Debenham's claim that she serves divine justice by shouting, "Then let God administer it, not you!" (qtd. in Makinen and Phillips 47). The 2017 film elaborates further on the fraught ethics of concealing the crime with a climax of emotional pyrotechnics where Poirot tearfully requests to be shot rather than live with a lie, saying, "You must silence me. Bouc can lie. I cannot," and then bellowing, "Do it!" In the final shot Poirot washes his hands of the affair, walking off the train alone in disillusionment.

Equally, the stereotypes become increasingly muted in film. The 1974 production is multilingual in announcements and dialogue, and preserves the ethnic portrayals, accents and animosities; Arbuthnot initially dismisses Poirot as "probably a frog." The movie continues the act-within-a-play of the pretended stereotypes but also adds a fourth-wall joke by having actors play personas unlike their signature ones-Sean Connery as suave James Bond is now stiff, brusque Arbuthnot, and Lauren Bacall, formerly Humphrey Bogart's elegant co-star in To Have and Have Not (1944), is now dowdy, blathering Hubbard (Kahn 209). The 2017 film makes the train and its passengers more uniformly American and most speak an undifferentiated English. The film is also more moralizing about bigotry, as Poirot scolds MacQueen for holding “a man's race against him” and Debenham chides Hardman over a racist remark made against Arbuthnot, who is black. But something has been cheapened, for the 2017 passengers 
were lying to Poirot, but not pretending to be anything besides innocent; that is what they are like. Little suggests they revert into their other, authentic selves (Arbuthnot's skin cannot be an act), and so evidently Count Andrenyi is a brawler and Mrs. Hubbard is a cynical, oversexed vamp. The film is flattened by deleting the evocative exposure of the passengers' ethnic identities as staged stereotypes.

In summary, our $\mathrm{A} / \mathrm{B}$ test shows the expected result: where Poirot and his values are not normative to or validated by the story, and where the stereotypes are minimized and the passengers merely pretend to be innocent, the narrative becomes less about Poirot's thought processes and the case as a mental game, and more about physical plot events. The results may be more visually gratifying, but the psychological and intellectual subtleties and depths of Murder are reduced with these two changes.

\section{CONCLUSION}

Whatever complaints Agatha Christie made about Poirot, his values are Murder's normative and narratorial values, and are coterminous with the train line's moral framework via his friend Bouc. Their performances of such national or ethnic clichés serve multiple purposes-in being amusing, in confusing Poirot, and in fulfilling a basic move of detective fiction by tempting the reader to follow red herrings in order to heighten surprise (Alexander 25). Yet I have attempted to show that the passengers' pretended stereotypical flaws also ensure the reader's awe of and sympathy for Poirot by contrasting against his genteel gravitas, so much so that the characters incline to resemble him in grace and generosity. As Christopher Cannon writes about chivalry, a medieval romance "represent[s] its ethics as so compelling that anyone who confronts the court inevitably becomes a part of it" (20). Here as well, in a different era, the passengers are reconciled with the reader's view of Poirot as they come to admire him for his valor and little grey brain cells, calling him "a very wonderful man" (Christie, Murder 262), and the story ends with concord on his terms as they continue home.

Murder on the Orient Express is not always subtle. For all its disapproval of the passengers' misappraising Poirot, the text too often also judges by physical appearances (Lahlmangaihi 15) or resorts to obvious aptronyms (Hard-man, Rat-chett, Dragon-miroff). While Christie's views would mellow (Prior 200), some of her earlier racism is problematic, and her palette of identities in Murder mostly includes Euro-Western ones. Yet the story implies that if national and ethnic stereotypes are only a performative stance, then such differences are superficial or dubious. In a field of 
action whose values remain dominated by Poirot's continental and Gallic mores, and where everyone is admittedly of a narrow and fairly wealthy demographic, such a hinted message of anti-prejudice freighted under other content is not a deep or wide one. But in the context of 1934, it is significant, and for Poirot's and Murder's continuing resonance, it remains so.

\section{Works Cited}

Alexander, Marc. "Rhetorical Structure and Reader Manipulation in Agatha Christie's Murder on the Orient Express." Miscelanea, vol. 39, 2009, pp. 13-27.

Allmendinger, Blake. "The Erasure of Race in Agatha Christie's And Then There Were None.” ANQ, vol. 32, no. 1, 2019, pp. 60-64. https://doi. org/10.1080/0895769X.2018.1469087

Bargainnier, Earl F. The Gentle Art of Murder: The Detective Fiction of Agatha Christie. Bowling Green, 1980.

Barnard, Robert. A Talent to Deceive. Dodd, Mead, 1980.

Beaumont, Matthew. "Cutting Up the Corpse: Agatha Christie, Max Ernst, and Neo-Victorianism in the 1930s." Lit: Literature Interpretation Theory, vol. 20, no. 1-2, 2009, pp. 12-26. https://doi. org/10.1080/10436920802690380

Bright, Brittain. "Writing Through War: Narrative Structure and Authority in Christie's Second World War Novels." Agatha Christie Goes to War, edited by Rebecca Mills and James Bernthal, Routledge, 2019, pp. 4662. https://doi.org/10.4324/9780367855185-4

Cannon, Christopher. Middle English Literature. Polity, 2008.

Cawelti, John G. "The New Mythology of Crime." Boundary 2, vol. 3, no. 2, 1975, pp. 324-57. https://doi.org/10.2307/302105

Chandler, Raymond. "The Simple Art of Murder." University of Texas at Austin, http://www.en.utexas.edu/Classes/Bremen/e316k/316kprivate/ scans/chandlerart.html, accessed 7 Oct. 2020.

Christie, Agatha. An Autobiography. HarperCollins, 2011.

Christie, Agatha. Murder on the Orient Express. William Morrow/Harper Paperbacks, 2011.

Dalal, Radha. "Spaces of the Past: Nostalgia in the Murder on the Orient Express and The Last Express." Engaging with Videogames, edited by Dawn Stobbart and Monica Evans, Inter-Disciplinary, 2014, pp. 26576. https://doi.org/10.1163/9781848882959_026

Ewers, Chris. "Genre in Transit: Agatha Christie, Trains, and the Whodunit." Journal of Narrative Theory, vol. 46, no. 1, 2016, pp. 97 120. https://doi.org/10.1353/jnt.2016.0009 
Gore-Langton, Robert. "The 'Detestable, Bombastic, Egocentric' Detective-Hercule Poirot Lives On.” The Spectator, 1 Feb. 2014, https://www.spectator.co.uk/2014/02/murder-motive-and-moustachery, accessed 7 Oct. 2020.

Grella, George. "Murder and Manners: The Formal Detective Novel." Novel: A Forum on Fiction, vol. 4, no. 1, 1970, pp. 30-48. https://doi. org $/ 10.2307 / 1345250$

Hall, Lucy, and Gill Plain. "Unspeakable Heroism: The Second World War and the End of the Hero." Heroes and Heroism in British Fiction Since 1800, edited by Barbara Korte and Stefanie Lethbridge, Palgrave Macmillan, 2017, pp. 117-34. https://doi.org/10.1007/978-3-31933557-5_7

Hark, Ina Rae. "Impossible Murders: Agatha Christie and the Community of Readers." Theory and Practice of Classic Detective Fiction, edited by Jerome H. Delmater and Ruth Prigozy, Greenwood, 1997, pp. 111-18. Hark, Ina Rae. "Twelve Angry People: Conflicting Revelatory Strategies in Murder on the Orient Express." Literature/Film Quarterly, vol. 15, no. 1, 1987, pp. 36-42.

Hawkes, David. "Agatha Christie." Mystery and Suspense Writers, Volume 1, edited by Robin N. Winks and Maureen Corrigan, Charles Scribner's Sons, 1988, pp. 195-216.

Heilbrun, Carolyn. "Keynote Address: Gender and Detective Fiction." The Sleuth and the Scholar, edited by Barbara A. Rader and Howard G. Zettler, Greenwood, 1988, pp. 1-10.

Kahn, Irene. "Agatha Christie and the Detective Film: A Timetable for Success." Literature/Film Quarterly, vol. 3, no. 3, 1975, pp. 205-14.

King, Stewart. "E Pluribus Unum: A Transnational Reading of Agatha Christie's Murder on the Orient Express." Clues, vol. 36, no. 1, 2018, pp. 9-19.

Lahlmangaihi, Z. D. "A Study of Power Dynamics in Select Novels by Agatha Christie.” 2014. Mizoram University, M.Phil. thesis.

Lassner, Phyllis. "The Mysterious New Empire: Agatha Christie's Colonial Murders." At Home and Abroad in the Empire: British Women Write the 1930s, edited by Robin Hackett, Freda Hauser and Gay Wachman, U of Delaware P, 2009, pp. 31-50.

Light, Alison. Forever England: Femininity, Literature and Conservatism Between the Wars. Routledge, 1991.

Linares, Trinidad. "Dis-Orienting Interactions: Agatha Christie, Imperial Tourists, and the Other.” 2018. Bowling Green State University, MA thesis.

Lutkus, Alan. "Agatha Christie.” The Crime Novel, edited by Tony Hilfer, U of Texas P, 1990, pp. 72-80. 
Makinen, Merja. "Agatha Christie (1890-1976)." A Companion to Crime Fiction, edited by Charles J. Rzepka and Lee Horsley, Blackwell, 2010, pp. 415-26. https://doi.org/10.1002/9781444317916.ch33

Makinen, Merja, and Patrick Phillips. "Transforming Justice? Murder on the Orient Express 1934-2010.” Clues, vol. 34, no. 1, 2016, pp. 41-51.

Marine, Brooke. "Kenneth Branagh's Ridiculous Mustache Will Almost Certainly Return in Murder on the Orient Express Sequel." W Magazine, 21 Nov. 2017, https://www.wmagazine.com/story/murder-on-theorient-express-sequel-death-on-the-nile-kenneth-branagh, accessed 7 Oct. 2020.

Martin, Eric. "Agatha Christie, Hercule Poirot, and Reverse Modernism." Pop Matters, 16 Jun. 2015, https://www.popmatters.com/187404agatha-christie-and-reverse-modernism-2495598741.html, accessed 7 Oct. 2020.

Mills, Nancy. "The Case of the Vanishing Mystery Writer: Christie Liked Only Two of the 19 Movies Made from Her Books." Chicago Tribune, 30 Oct. 1977, p. 44.

Munt, Sally. Murder by the Book? Feminism and the Crime Novel. Routledge, 1994.

Murder on the Orient Express. Directed by Kenneth Branagh, performances by Kenneth Branagh and Penélope Cruz, Twentieth Century Fox, 2017.

Murder on the Orient Express. Directed by Philip Martin, performances by Eileen Atkins and David Suchet, Government of Malta/ITV Studios/ WGBH, 2010.

Murder on the Orient Express. Directed by Sidney Lumet, performances by Lauren Bacall and Albert Finney, EMI Films, 1974.

Pendergast, Bruce. Everyman's Guide to the Mysteries of Agatha Christie. Trafford, 1994.

"Poirot is Not Comical, Agatha Christie's Family Tells Actor." Sydney Morning Herald, 4 Jun. 2013, https://www.smh.com.au/ entertainment/tv-and-radio/poirot-is-not-comical-agatha-christiesfamily-tells-actor-20130604-2nnhy.html, accessed 7 Oct. 2020.

Prior, Christopher. "An Empire Gone Bad: Agatha Christie, Anglocentrism and Decolonization." Cultural and Social History, vol. 15, no. 2, 2018, pp. 197-213. https://doi.org/10.1080/14780038.2018.1427354

Ro, Christine. "Agatha Christie Shaped How the World Sees Britain." BBC Culture, 7 Sept. 2018, http://www.bbc.com/culture/story/20180907agatha-christie-shaped-how-the-world-sees-britain, accessed 7 Oct. 2020.

Rowland, Susan. From Agatha Christie to Ruth Rendell. Palgrave Macmillan, 2001. https://doi.org/10.1057/9780230598782 
Schaub, Melissa. "Middlebrow Feminism and the Politics of Sentiment: From The Moonstone to Dorothy L. Sayers." Modern Language Studies, vol. 43, no. 1, 2013, pp. 10-27.

Singer, Eliot A. "The Whodunit as Riddle: Block Elements in Agatha Christie.” Western Folklore, vol. 43, no. 3, 1984, pp. 157-71. https:// doi.org/10.2307/1499897

Slung, Michele. "Let's Hear It for Agatha Christie: A Feminist Appreciation." The Sleuth and the Scholar, edited by Barbara A. Rader and Howard G. Zettler, Greenwood, 1988, pp. 63-68.

Suits, Bernard. "The Detective Story: A Case Study of Games in Literature." Canadian Reviere of Comparative Literature, vol. 12, no. 2, 1985, pp. 200-19.

York, R. A. Agatha Christie: Power and Illusion. Palgrave, 2007. https:// doi.org/10.1057/9780230590786

\section{Kenneth (Ken) Eckert is a Canadian and Associate} Professor of English at Hanyang University ERICA in Korea. He teaches British literature, including Shakespeare, modernism and postmodernism. He has published on Chaucer, medieval romance, satire and 1950s literature, and recently published a humor novel, Shorter of Breath.

https://orcid.org/0000-0002-6514-0894

keneckert@hanyang.ac.kr 